\title{
Caregiver experience in preventive treatment for children exposed to Human Immunodeficiency Virus
}

\author{
Experiência do cuidador no tratamento preventivo da criança exposta ao Vírus da \\ Imunodeficiência Humana
}

\section{Experiencia del cuidador en el tratamiento preventivo de niños expuestos al Virus de la Inmunodeficiencia Humana}

\author{
Mariana Ramos da Silva ${ }^{1}$, Willyane de Andrade Alvarenga ${ }^{2}$, Giselle Dupas ${ }^{1}$
}

This study aimed to understand the experience of caregivers of children vertically exposed to the Human Immunodeficiency Virus. It used Symbolic Interactionism as a theoretical framework. It is a qualitative research with data collection carried out in a reference clinic in a municipality in the state of São Paulo, from November 2012 to August 2013 through semistructured interviews with 12 mothers and a grandmother. Data were analyzed using the Content Analysis method. The caregivers administered antiretroviral to child to prevent virus infection and perceived good acceptance of medication. The child was considered healthy and waiting for the test results generated suffering. Family support and public health services were highlighted as an aid to go through this route pervaded by prejudice, lack of direction, fear and inability to breastfeed. It was noted that the public health service in the city studied tried to follow the protocol requirements established, however, improvements in the quality of counselling is needed.

Descriptors: HIV Seropositivity; Infectious Disease Transmission, Vertical; Child; Nursing Care; Pediatric Nursing; Family.

Objetivou-se conhecer a experiência de cuidadores de crianças expostas verticalmente ao Vírus da Imunodeficiência Humana. Utilizou Interacionismo Simbólico como referencial teórico. Pesquisa qualitativa com coleta de dados realizada em ambulatório de referência, em município no interior do estado de São Paulo, Brasil, entre novembro/2012 e agosto/2013, por meio de entrevista semiestruturada com 12 mães e uma avó. Dados analisados utilizando-se método Análise de Conteúdo. Cuidadoras administraram antirretroviral à criança para evitar infecção pelo vírus e perceberam boa aceitação da medicação. Criança considerada saudável e esperar pelos resultados de exames gerou sofrimento. Apoio da família e do serviço público de saúde foram ressaltados como auxílio para percorrer esse caminho permeado por preconceito, falta de orientação, medo e impossibilidade de amamentar. Observou-se que o serviço público de saúde do município estudado tentou seguir as exigências protocolares estabelecidas, porém, é necessário melhorias na qualidade do aconselhamento.

Descritores: Soropositividade para HIV; Transmissão Vertical de Doença Infecciosa; Criança; Cuidados de Enfermagem; Enfermagem Pediátrica; Família.

El objetivo fue conocer la experiencia de cuidadores de niños verticalmente expuestos al Virus de la Inmunodeficiencia Humana. Se utilizó el interaccionismo simbólico como marco teórico. Investigación cualitativa con recolección de datos en ambulatorio de una ciudad de São Paulo, Brasil, entre noviembre/2012 y agosto/2013 a través de entrevistas semiestructuradas con 12 madres y una abuela. Datos fueron analizados según el Análisis de Contenido. Cuidadores administraban antirretroviral al niño para prevenir infección por virus y percibieron buena aceptación de la medicación. El niño fue considerado saludable, y esperar por los resultados de pruebas generaba sufrimiento. Apoyo de la familia y del servicio de salud pública se destacaron como ayuda para seguir este camino lleno de prejuicios, falta de orientación, miedo e incapacidad de amamantar. El servicio de salud pública de la ciudad investigada intentó seguir los requisitos del protocolo establecido, pero, necesita de mejorías en la calidad del asesoramiento.

Descriptores: Seropositividad para VIH; Transmisión Vertical de Enfermedad Infecciosa; Ninõ; Atención del Enfermería; Enfermería Pediátrica; Familia.

\footnotetext{
${ }^{1}$ Universidade Federal de São Carlos. São Carlos, SP, Brazil.

${ }^{2}$ Escola de Enfermagem de Ribeirão Preto, Universidade de São Paulo. Ribeirão Preto, SP, Brazil

Corresponding author: Giselle Dupas

Universidade Federal de São Carlos, Departamento de Enfermagem. Rodovia Washington Luís, km 235, Jardim Guanabara, CEP: $13565-905$. São Carlos, SP, Brazil. E-mail: giselle.dupas@gmail.com
} 


\section{Introduction}

The number of infections by human immunodeficiency virus (HIV) increased from 1.8 in 1990 to 14.7 in 2011, among women, especially among those who were in the reproductive age ${ }^{(1)}$. This feminization process increased the incidence of vertical transmission (VT), that is, the transmission of HIV from mother to child.

To reduce the number of children infected in the last decade, some efforts have been made, which brought satisfactory results. There was a fall of $43 \%$ between the years 2003 and 2011, and, in the last two years, a reduction of $24 \%{ }^{(2)}$ of infected children from the expansion of women's access to anti-HIV serological triage in prenatal ${ }^{(3)}$ and the prophylactic prevention of those living with HIV. Antiretroviral therapy (ARVT) and the replacement of breastfeeding prevented 409,000 children from acquiring HIV infection in low- and middle-income countries from 2009 to $2011^{(2)}$.

When prophylactic measures are carried out, it is possible to reduce VT to less than $1 \%$ VT. This is due to factors like the use of ARVT during pregnancy and labor, elective cesarean section for women with high or unknown viral load, the use of ARVT by the newborn and the replacement of breastfeeding by infant formula (powdered milk). When not performed, the rate of transmission of HIV can range from 25 to $30 \%$ (4).

Considering these cautions, gestating with HIV seropositivity diagnosed is difficult for women, even when there is a desire to have the child in the presence of the virus ${ }^{(5)}$. Family support is essential in coping with the disease, once the fear of contaminating the child is always present. Moreover, beliefs and religion $^{(6)}$ can influence the way they deal with the diagnosis itself. Moments of guilt, shame, among other negative feelings can interfere both in everyday life and in the care given to their children.

How the mother or caregiver deals with the care to the child, with the consequences of living with
HIV and the pregnancy under the risk of having a child infected by viruses highlights the importance of a support network in which the health professional is prominent. The caregiver, in this study, is defined by the person who is responsible for taking care of the child and who is aware of the vertical exposure condition.

The theoretical referential adopted, Symbolic Interactionism, will allow understanding the interactions and meanings derived from social relations established by the caregiver. These established relationships are important to the actions, for self-perception and the environment in which he/she experien$\operatorname{ces}^{(7)}$. In this perspective, weaknesses and strengths in the accomplishment of treatment to the child and how the mother or caregiver faces the trajectory of confirmation, or not of the HIV diagnosis in children, can be identified. Therefore, this research aimed to understand the experience of children caregiver exposed vertically to HIV children.

\section{Method}

This research uses an exploratory, descriptive and qualitative approach. The theoretical referential used was the Symbolic Interacionism, a perspective that allows exploring the knowledge and practices of people on certain matters or their experiences. Therefore it allows analyzing the processes of socialization, as well as behaviours and expectations, since it has social interaction as the basic unit, responsible for the way man acts and the meanings constructed in contexts of interaction ${ }^{(7)}$.

The study was carried out from November 2012 to October 2013. Data collection was conducted at the Municipal Centre of Specialties, located in a municipality in the state of São Paulo. A reference center that has a Specialized Assistance Service to HIV-positive individuals or children from infected mothers. During the period of data collection, the service had 17 children exposed in monitoring.

The survey was conducted with 12 mothers and a grandmother of children exposed to HIV. The 
criteria for inclusion were: be a child caregiver, aged up to 18 months, without complete definition of HIV infection (infected or not infected/serum-reverted) and in pediatric monitoring in the clinic. On the other hand, the exclusion criteria were: the caregiver being less than 18 years old and unaware of the child's vertical exposure to HIV condition.

Potential participants were identified from medical records of children in care and observation of the consultation agenda. Following this survey, the caregiver was approached moments before the child consultation and invited to a private room, where the research objectives were explained and the invitation to participate was performed.

Data collection occurred in two periods, with the intention of providing greater density to the results and to verify the emergence of new information. The first data collection occurred from November 2012 to March 2013, which resulted in 10 participants, being conducted seven interviews. There was a refusal and two mothers did not attend the scheduled visits. The second moment occurred from May to August 2013, seven families were selected and six new interviews were performed. A mother could not be invited to interview, because she did not attend two consecutive consultations.

The semi-structured interview was applied, with an average duration of 40 minutes. Single meetings were held with the main researcher. The guiding questions were: "How was the period of preventive treatment to reduce your child's chances of seropositivity to HIV? How are the child's health and illness condition and which health services you have tried to monitor the child? ".

To ensure the anonymity of interviewed persons, mothers were identified by the word "mother" and the grandmother for the word "grandmother", followed by the number. There is no number followed by the word "grandmother" because there was only one being interviewed. There was the approval of the Ethics Committee in Humans Research of the Federal University of São Carlos (Case No. 72127/2012) to conduct this research and the guidelines contained in the Resolution of the National Health Council 196/96.

\section{Results}

13 participants, 12 mothers and a grandmother, aged between 18 and 58 years old were interviewed. The children were between 1 and 19 months old, mostly women (54\%) and the first child vertically exposed to HIV (69\%). Regarding the discovery of the diagnosis of seropositivity, $62 \%$ of the mothers discovered it during pregnancy, $31 \%$ before pregnancy and $7 \%$ after birth. Among those interviewed, there was a predominance of family income between one and two minimum wages.

The analysis of information ${ }^{(8)}$ was used to investigate the experience of the caregiver in preventive treatment for HIV exposed children. The testimonials were fully transcribed, read and the significant excerpts that meet the objectives were highlighted. Then, the speeches that resembled were grouped, allowing the construction of the following categories: Caregivers understanding regarding preventive actions, Expectation about the results of examinations, Need for support measures to care for the child, Coping with difficulties during treatment and Frustration for not breastfeeding.

\section{Caregivers understanding regarding preventive actions}

After birth, mothers and relatives of children exposed to the virus begin to provide care as the instructions received by health professionals, administering medications such as zidovudine (AZT), sulfamethoxazole + trimethoprim (Bactrim), ferrous sulfate and vitamins.

The oriented therapeutic approach in the use of AZT in children, according to the vast majority of the interviewees lasted 40 days, starting at maternity and continuing at home. When my daughter was born, she has begun to take this AZT syrup. When I left maternity, I kept giving 
during 40 days and then stopped. In addition to this medication, she took vitamin and iron sulfate (mother5). I gave AZT to him [the child] at home; I think for a month and a half or so and then started with Bactrim (mother11).

The way children received these medications was described as good, with no reports of adverse reactions or rejection. I think my son felt nothing when he took the drug. "Everyone" said it was sweetie, so I think, he felt nothing (mother9).

The caregivers consider their children healthy, possessing health status befitting their age. The diseases presented were not related to the mother's HIV seropositivity or the child's exposure to the virus, but to other factors such as weather conditions, interaction between children and the environment. With two months my daughter had bronchiolitis, but it was because of the cold, I treated at home, she was well soon and then had nothing else. I see that she is healthy (mother1). My daughter was not hospitalized, had no type of infection. Only now she got sick because of age, because she interacts with objects, floor and the risk of contamination increases (mother2).

In addition to the recommended care, caregivers have adopted postures that overprotected and distanced themselves from their children because they fear of contaminating them with HIV or other diseases. I do not kiss my children; I do not let them walk barefoot. Cup, plate, fork, towel, clothes, nail cutter, pliers, tweezers, nail polish are all apart. Sometimes I wash him [child] with coarse salt and the bathtub with alcohol. I was also advised not to mess with things that stick like needle, and not to leave it near them (mother4).

\section{Expectation about the results of examinations}

Waiting confirmation or not of HIV infection in children is experienced with a combination of feelings like fear, anxiety and moments of relief. The expectation of the result is so intense that turns into a despair that goes until the doctor reveals the diagnosis. It is anguish, sadness, despair, grief that has no size. You take the exam today and it feels like the day took about 30 years to end, until you pick up the result. The time you receive it, it seems you will have a heart attack, until the doctor say "oh, it was negative." My fear is to have a positive result (mother4).

When this result meets what is expected, the negativity for HIV, the relief is the prevailing sentiment. This result gives hope and faith in not having an infected child. It was an anxious wait for the results of her examination [child]. Since she was born, I wanted to know, but the doctor said it's okay, it was negative. Thank God! I hope everything goes well with the others (mother8). I believe, I have faith that it will be negative. The doctor said that it was negative so far, so I should keep expecting it to always be negative (mother5).

\section{Need for support measures to care for the child}

At maternity hospital, children receive primary care, guidelines regarding medications and schedule an appointment at the reference service. It was in the maternity where they guided me about the drug [infant AZT]. The professionals there started giving these remedies, and when I was able to leave, the consultation in here [Service Specialist Service] was already scheduled (mother4).

After hospital discharge, mothers need support and help to go through this path with the child. They ascribe to the family the various types of support received, especially in times of great suffering. Most often, the grandmother and her partner/father of the child are the ones who provide support. I think I infected myself through my husband, but we are even more linked. My family also knows I'm HIV positive; at first it was difficult, but they are supporting me and help me when something that is missing (mother7).

By revealing to their family the seropositivity, many continued to receive support, however some have omitted the diagnosis for fear of losing the support received. In my family, my mother and my sisters help me take care of them [children], but no one knows about my problem, because was afraid to tell (mother6).

Health services are part of the path that the family goes through with the child, since this requires monitoring as to the evolution of HIV status. Professionals such as doctors, nurses, nurse technicians and psychologists have offered guidance on how to admi- 
nister the medication, emotional support, and provide free artificial milk. In this context, public services were the most used. I just bring my daughter here [Specialized Assistance Service] and also take her to the health center to take the vaccine. The hospital, I went only when she had pneumonia (mother3). I pick up 10 cans of milk per month here [Specialized Assistance Service]. When I left maternity, the professionals left the prescription along with the drug [AZT] all well explained (mother9).

In contrast, there was a preference for private health service to monitor the child. The only link with the public service was through the free receiving of infant formula and vaccines. I come here [Specialized Assistance Service], for milk, but if not, it would be only for the private sector because it is more convenient. I go to the health center only for the vaccine (mother1).

The caregivers evaluate as positive the conduct of health professionals working in specialized service. I think that the professionals are really cool in here [Specialized Assistance Service], because they treat us very well, like a normal person; nobody is prejudiced (mother11).

\section{Coping with difficulties during treatment}

Prejudice, discrimination and lack of family support were difficulties pointed that resulted in the omission of proper diagnosis and isolation of those living with HIV or at risk to acquire it as a child. I told one of my brothers that my daughter is HIV and he told the others. I have a son who is very biased, he does not know to this day about my daughter. So I promised to myself, to not tell anyone else (grandmother).

The fear of the diagnosis discovery meant that women did not like to attend the service because it could be a form of exposure that would reveal the HIV status by virtue of being a specialized care for people with HIV. I feel a bit exposed when I come here [Specialized Assistance Service] because there is where we are consulted there are a lot of HIV signs and I think people are suspicious (mother8).

The action of revealing the diagnosis o the family is driven by the idea of receiving support. However, this is not always offered by every family member, in some cases occurring helplessness and rejection to the mother and child. I was very discriminated when I told my family, I thought I would be supported, but no. I went to the street, had to live alone, they were "disgusted" of me and my daughter (mother2).

\section{Frustration for not breastfeeding}

With the diagnosis of living with HIV, mothers were instructed not to breastfeed, this moment is experienced with sadness, disappointment and guilt because the deprivation was perceived as a broken dream. There were moments when they recognized the true reason for not to breastfeed. Breastfeeding for me is a dream that we are not allowed. It was the biggest disappointment; I cried, did not accept, but I have to be aware that I can not. Wanting to breastfeed means I want to contaminate my daughter (mother2).

Another difficulty faced by mothers was dealing with issues related to not breastfeeding. Considering this situation they invented excuses, omitting the true cause of breastfeeding cessation. I tell people that I do not breastfeed because I had anemia and the doctor said it was too strong so I could not breastfeed. Sometimes I say that milk did not come down (mother7).

Due to non-breastfeeding the mothers received shortly after the birth of the child medicine to inhibit lactation, and sometimes, it was also necessary to carry out the breasts bandage. I took the medicine to dry the milk and bandaged my breasts. Even before having my daughter, nothing was coming out, but I took it anyway (mother12).

When the mother has ever experienced breastfeeding in previous pregnancies or not yet experienced this situation because it's her first child, perform this restriction has become even more complex and costly. For me it was hard not to breastfeed because my other three children I breastfed. They gave me the medicine to dry the milk, but it did not dried, so they [professionals from the maternity] gave me another dose of the drug (mother3). Ah, that's the worst part [not breastfeed] because every mother dreams of breastfeeding (mother1).

In contrast, when a woman did not breastfeed in previous pregnancy, this process becomes less painful, but not easier. The non-feeding may mean depriving the child of the benefits of breast milk. It was hard for me because I always dreamed of being a mother and always 
dreamed of breastfeeding. I think it's beautiful and healthy for the child. The first pregnancy I suffered more than this, because in this one I was already used. But we feel a little guilty (mother6).

After the suspension of free milk distribution, caregivers adopt procedures consistent with their financial conditions, feeding the child, often with inappropriate milk to age and without proper guidance. I received artificial milk until he was six months. Now, they [health professionals] suspended it, and told me to see if he [child] would get used to other milk, cow's milk, but they didn't guide me. They just told me to see if he [child] would get used to other milk (mother10).

\section{Discussion}

In order to reduce the occurrence of VT, the caregiver must follow a series of precautionary recommendations, during and after pregnancy. In Brazil, the Ministry of Health recommends that, in the delivery room or within the first two hours after birth, the child receives the first dose of zidovudine and maintenance of the treatment during the first six weeks of life (42 days) $)^{(4)}$. This measure is consistent with the guidelines of the United States that use oral AZT for six weeks. However, in the United Kingdom, the chemoprophylaxis for children with low-risk of VT is applied for four weeks ${ }^{(9)}$.

In addition to AZT, in order to prevent pneumonia, it is recommended that all HIV-exposed children receive as primary prophylaxis the trimethoprim-sulfamethoxazole, from the $6^{\text {th }}$ week of life, until the completion of 1 year old, unless the virus infection can be removed ${ }^{(10)}$.

This study identified failures during the orientation process for caregivers, because the participants reported conflicting information regarding the recommended medications. They cited less than 42 days of AZT administration period and few children made use of trimethoprim-sulfamethoxazole. In contrast, as disclosed, despite the time of use of AZT, most children receive the drug after the first hours of life $\mathrm{f}^{(11)}$.

The caregivers rated as positive the reaction of the children on the use of medications because they had good acceptance without adverse reactions. Similar result reinforces the acceptance of medication by their children ${ }^{(12)}$.

Living with the doubt if the child was or not infected, caregivers adopt preventive measures at home, as the distancing from their children in an attempt to avoid contamination. This attitude may be related to lack of information about the transmission pattern for HIV. The overprotection of the child appears as a compensation mechanism that mothers adopt to overcome the feelings of guilt and anxiety, dispensing excessive care to their children ${ }^{(5)}$.

Regarding the health of the child, the caregivers perceive it as healthy, as there was no need for hospitalization, despite the manifestation of some common childhood illnesses, such as influenza, pneumonia, bronchiolitis and diarrhea. Due to different immunological factors there are children who need hospitalization due to infections such as bronchitis and bronchiolitis $^{(13)}$.

However, due to the period of uncertainty, one of the main concerns of caregivers was about the child's diagnosis. Families were experiencing feelings like anxiety and despair, whose biggest worry was the possibility of a positive diagnosis. While the temporary result is negative, hope and relief replaced the anguish and guilt. Similar findings indicate that this waiting is experienced with periods of fear, anguish and concern ${ }^{(12-13)}$.

At this moment, faith and spirituality are strategies that reduce the suffering and sustain hope. These factors are cited as ways to alleviate suffering and increase hope the child does not get infected ${ }^{(6,13)}$.

After birth, the caregivers experienced a new and unknown world filled with uncertainties, which may cause sadness. Therefore, the family plays an important role in providing support, making this journey less painful and lonely ${ }^{(6,12-14)}$. The support and understanding helped caregivers to overcome difficulties by providing them safety for the fulfillment of the treatment.

Similar to the present study, financial aid, emo- 
tional support, companionship, provision of shelter, help in caring for the child and the home are assistance given by family ${ }^{(13)}$. However, there also were mothers who omitted from their families the diagnosis of seropositivity, since they feared losing this support with the discovery of their HIV status. This secrecy may be related to the anticipated fear of prejudice, because even today, HIV/Aids is a disease permeated with discrimination. Women hide their serology and end up walking away voluntarily from family for not having the intention to disclose the diagnosis ${ }^{(5,13,15-16)}$. This attitude permeates feelings of fear and abandonment since they end up living in a social isolation, making this a solitary process.

So when the family does not accept the positive diagnosis for HIV, adopting a prejudiced attitude, they produce barriers that hinder coping with the disease, providing psychological distress and feelings of abandonment $^{(17)}$. The results of this study show that two women suffered prejudice within the family network, which triggered the silent and solitary experiences, causing overload. Research in different regions of Brazil indicate similar data ${ }^{(6.12-13.15)}$, showing that prejudice is universal.

However, health professionals have fulfilled their roles as welcoming because most caregivers praised the services where they passed. The support of professionals is revealed with expressions of affection and respect ${ }^{(14)}$. In contrast, there were professionals who showed prejudice, discrimination and dehumanization, showing the unpreparedness of the people who work in referral services to this population $^{(5,16)}$.

The caregivers need quality care, carried out by trained professionals, because discrimination hinders the process of acceptance of the disease by those living with HIV. Most of these people chose to isolate themselves due to fear of suffering prejudice and stigma from others and many of them also had these feelings for themselves. Fact that inhibited them to attend health services because they believed that this environment could be revealing the serology. The an- xiety and concern for the possibility of being discovered permeated the maternal experience ${ }^{(5)}$.

Health services also contribute with the care, since the child exposed to the virus needs to be accompanied by a specialized service, where the first consultation must not exceed thirty days after bir$\mathrm{th}^{(10)}$. All children in this study were being followed at the time of the interview, which was also highlighted previously ${ }^{(18)}$.

Public health services were the most used by mothers and children in this study. This scenario is characterized by low family income, since the vast majority of participants lived with up to two minimum wages per month, complicating the access to private institutions. Other aspects is the fact that the drugs to treat HIV/Aids are offered free by the National Health System to people enrolled in reference services ${ }^{(19)}$, opening the doors of the public system for all citizens, including those who have conditions and prefer to attend the private service. Furthermore, the demand of the interviewed for the public health services in order to vaccinate their children may be related to the wide availability of free and good quality biopharmaceuticals.

Regarding breastfeeding, due to the presence of the virus in the milk of women living with HIV, it should be discouraged and is considered an additional risk for VT, ranging $7-22 \%$, leading to the $29 \%$ chance of contamination that is renewed each exposure (breastfeeding). Therefore, women need to receive medication to inhibit lactation after delivery. The mechanical inhibition of lactation by bandaging the breasts, is recommended when the drug was not effective ${ }^{(4)}$. The majority of respondents in this survey reported that they did exclusive use of drug inhibiting lactation and few bandaged breasts after the birth of their children. In contrast, inhibition by the combination of hormonal and mechanical method was the most used, followed by the exclusive use of mechanical method, being the hormonal method the least used ${ }^{(20)}$.

Deprivation of breastfeeding becomes difficult when the mother has that desire. Many people may 
question them about the reason for not breastfeeding, raising doubts about the possibility of revealing the real reason. Many have decided not to speak and created excuses to evade the questions. Some think they are less mothers, or that they are hurting their baby by not offering breast milk ${ }^{(21)}$ and as justification, they cite that the milk is weak or it has dried ${ }^{(13)}$.

Not breastfeeding is one of the main difficulties for women living with HIV, with sadness, discomfort and inferiority feelings that prevail during this pe$\operatorname{riod}^{(12-13.15)}$. In addition, they suffer because they have learned that breast milk is the best food for the baby, however, due to virus infection, are unable to provide this source of nutrient for their children. These findings corroborate with our results, where respondents reported sadness, especially when ytehy have breastfed in other circumstances.

Furthermore, to overcome the desire to breastfeed, women resort to the real reason for the impossibility of overcoming as strategy since they recognized that breastfeeding could harm the health of their children. Overcoming this frustration may be related to the fear of child becomes contaminated with the virus, causing them to accept the recommendations and to offer the processed milk ${ }^{(12-13)}$.

Thereby, mothers living with HIV have the right secured by the Ministry of Health to receive free infant milk formula until the sixth month of life of their children. In the present study, all caregivers reported receiving cans of milk, free of charge, during the first months of life of their children.

After this period, the benefit was suspended, been unattended for information on how to select and prepare the child complementary feeding. With the lack of guidance, the caregivers were vulnerable to offer less nutrients than children's needs. Therefore, it is the role of health professionals to provide information, consistent with the level of education of mothers on how to prepare the milk or complementary foods needed to maintain the child's development ${ }^{(22)}$.

\section{Final Considerations}

This research helped identify the paths taken by the caregivers during the period of preventive treatment for HIV exposed children. The fear and uncertainty about the child's diagnosis permeated that period and the health professional had major importance, especially in relation to guidance on the administration of medications and offering infant formula.

The waiting for the results from the child's examinations and the inability to breastfeed were the most difficult moments to be faced in order to live with the uncertainty of the diagnosis and not breastfeeding has generated suffering, anguish and frustration. The support of family members and health professionals helped the caregivers in facing the difficulties.

Health professionals, including nurses, are fundamental to support families living with or affected by HIV to dispense advice on how to proceed during the preventive treatment of the child and remember the modes of transmission of the virus to reduce discrimination.

It was observed that the public health service in the studied municipality attempts to follow the requirements of the protocols established by the Ministry of Health in regard to dispensing the care to newborns exposed to HIV. However, to succeed in actions against vertical transmission there should be improvement in the quality of women counceling while pregnant and/ or laboring woman in addition to a human assistance, involving the family. When leaving the maternity, a woman should feel safe and educated as to the continuity of care in the home, so she won't increase children's exposure to the virus, since the absence of guidelines may jeopardize the success of the treatment and weakening women and the family for child care.

It is noteworthy that the data obtained can not be generalized due to the number of participants, the non-inclusion of the experience from families that make the follow-up in private services, since the 
survey was conducted in a public service, and the memory bias due to retrospective interviews model, which may have influenced the accuracy of the recollections of some facts.

It reflected about the practice of health professionals in this context, especially Nursing to improve the quality of care provided by advances in HIV treatment. The present study may provide awaken to new research on HIV and the role of Nursing in this context.

\section{Acknowledgements}

We thank the Fundação de Amparo a Pesquisa do Estado de São Paulo (No. 2012/16837-4) for funding this work resulting from a Scientific Initiation, professionals from the Municipal Center of Specialties and users assisted in this place, who contributed to the study.

\section{Collaborations}

Alvarenga WA and Silva RM contributed to the collection and interpretation of data, drafting and revising the article. Dupas G contributed with guidance, supervision and review of the article.

\section{References}

1. Ministério da Saúde (BR). Secretaria de Vigilância em Saúde. Boletim Epidemiológico, AIDS, DST. Versão Preliminar. Brasília: Ministério da Saúde; 2012.

2. Joint United Nations Programme on HIV/AIS (UNAIDS). World AIDS Day Report 2012. Geneva: WHO; 2012.

3. Ministério da Saúde (BR). Departamento de DST, Aids e Hepatites Virais. AIDS no Brasil. Brasília: Ministério da Saúde; 2010.

4. Ministério da Saúde (BR). Secretaria de Vigilância em Saúde. Programa Nacional de DST e AIDS. Recomendações para profilaxia da transmissão vertical do HIV e terapia antirretroviral em gestantes: manual de bolso. Brasília: Ministério da Saúde; 2010.
5. Galvão MTG, Cunha GH, Machado MMT. Dilemas e conflitos de ser mãe na vigência do HIV/Aids. Rev Bras Enferm. 2010; 63(3):371-6.

6. Galvão MTG, Lima ICV, Cunha GH, Santos VF, Mindêllo MIA. Estratégias de mães com filhos portadores de HIV para conviverem com a doença. Cogitare Enferm. 2013; 18(2):230-7.

7. Carvalho VD, Borges LO, Rego DP. Interacionismo simbólico: origens, pressupostos e contribuições aos estudos em Psicologia Social. Psicol Cienc Prof. 2010; 30(1):146-61.

8. Bardin L. Análise de conteúdo. Lisboa: Edições 70; 2011.

9. Neubert J, Pfeffer M, Borkhardt A, Niehues $\mathrm{T}$, Adams $\mathrm{O}$, Bolten $\mathrm{M}$, et al. Risk adapted transmission prophylaxis to prevent vertical HIV-1 transmission: effectiveness and safety of na abbreviated regimen of postnatal oral Zidovudine. BMC Pregnancy Childbirth. 2013 13:22.

10. Ministério da Saúde (BR). Programa Nacional de DST e Aids. Recomendações para terapia antirretroviral em crianças e adolescentes infectados pelo HIV: manual de bolso. Brasília: Ministério da Saúde; 2009.

11. Freitas JG, Cunha GH, Barroso LMM, Galvão MTG. Administration of medications for children born exposed to human immune deficiency virus. Acta Paul Enferm. 2013; 26(1):42-9.

12. Rigoni E, Pereira EODS, Carvalho FT, Piccinini CA. Sentimentos de mães portadoras de HIV/Aids em relação ao tratamento preventivo do bebê. PsicoUSF. 2008; 13(1):75-83.

13. Gonçalves TR, Piccinini CA. Experiência da maternidade no contexto do HIV/Aids aos três meses de vida do bebê. Psicol Teor Pesq. 2008; 24(4):459-70.

14. Scherer LM, Borenstein MS, Padilha MI. Gestantes/ puérperas com HIV/Aids: conhecendo os déficits e os fatores que contribuem no engajamento para o autocuidado. Esc Anna Nery. 2009; 13(2):35965.

15. Cordova FP, Luz AMH, Innocente AP, Silva EF. Mulheres soropositivas para o HIV e seus companheiros frente à decisão pela gestação. Rev Bras Enferm. 2013; 66(1):97-102. 
16. Machado AG, Padoin SMM, Paula CC, Vieira LB, Carmo DRP. Análise compreensiva dos significados de estar gestante e ter HIV/Aids. Rev Rene. 2010; 11(2):79-85.

17. Li L, Liang LJ, Ding YY, Ji G. Facing HIV as a family: predicting depressive symptoms with correlated responses. J Fam Psychol. 2011; 25(2):202-9.

18. Barroso LMM, Galvão MTG, Cavalcante RM, Freitas JG. Cuidado materno aos filhos nascidos expostos ao HIV/AIDS. Rev Rene. 2009; 10(4):155-64.

19. Villarinho MV, Padilha MI, Berardinelli LMM, Borenstein MS, Meirelles BHS, Andrade SR. Políticas públicas de saúde face à epidemia da AIDS e a assistência às pessoas com a doença. Rev Bras Enferm. 2013; 66(2):271-7.
20. Lima CTD, Oliveira DR, Rocha EG, Pereira MLD. Manejo clínico da gestante com HIV positivo nas maternidades de referência da região do Cariri. Esc Anna Nery. 2010; 14(3):468-76.

21. Bisol C, Vazzano A, Bass J. Vivências de gestantes e mães com HIV. Caxias do Sul: Educs; 2012.

22. Freitas JG, Barroso LMM, Galvao MTG. Maternal ability to take care of children exposed to HIV. Rev Latino-Am Enfermagem. 2013; 21(4):964-72. 